\title{
Hiding for Survival: Highlighting the Lived Experiences of Precarity and Labour Abuse Among Filipino Non-status Migrants in Canada
}

\author{
Nellie Alcaraz ${ }^{1} \cdot$ Ilyan Ferrer $^{1}$ (D) . Jose Gabriel Abes ${ }^{1} \cdot$ Liza Lorenzetti $^{1}$ (D)
}

Accepted: 24 February 2021 / Published online: 31 March 2021

(c) The Author(s), under exclusive licence to Springer Nature Switzerland AG 2021

\begin{abstract}
Non-status migrants are individuals who do not hold a valid immigration document or official status to stay in Canada. This paper presents a case study on the experiences of non-status migrants seeking access to health, social, and community services. Through interviews with five non-status migrants, the authors explore the specific needs, rights, services and barriers they encountered. Our findings highlight five case-based themes that centre on the (1) undocumented and hidden costs of striving for status, (2) aspirations to stay in Canada, (3) navigation through the everyday struggles to survive, (4) acts of selflessness and (5) resistance against the stigmatisation of being labelled a non-status migrant. Despite their fear of exposure to professionals, non-status participants express willingness to utilise services in the community. However, there is considerable paucity of information about the resources that they could access freely and without risk. This paper offers key recommendations for social work practitioners who engage in social justice and advocacy work alongside non-status migrants in Canada.
\end{abstract}

Keywords Temporary foreign workers · Non-status migrants · Undocumented Filipino/a workers · Canadian migration

\section{Introduction}

"Why not [give us a chance] because I want to give my family a better future. Unlike [back home], I am just a son of a peasant; we could be the poorest people on earth. We try to withstand [our challenges here] because we still want to live. We are still fighting". -Manuel reflecting on his time as a non-status migrant in Canada.

With the proliferation of globalisation and the increasing flows of migration and labour, an unprecedented number of people navigate and negotiate a changing and often precarious maze of (im)migration programs, regulations, and brokers in search of official immigration status. Within Global North settler-societies, where status is a mechanism to control and reinforce what Thobani (2007) calls the 'exalted subject', immigration status is a fluid concept that offers accessibility, security and legitimacy to subjects of

Ilyan Ferrer

ilyan.ferrer@ucalgary.ca

1 Faculty of Social Work, University of Calgary, 2500

University Drive NW, Calgary T2N1N4, Canada the nation-state. However, immigration status is also fiercely guarded and regulated, wrought with barriers intentionally meant to limit who is socially, economically and physically considered legitimate applicants and subjects of permanent residency or citizenship.

An estimated $10-15 \%$ of the 20 to 30 million migrants around the world are non-status migrants, also known as undocumented persons who do not hold valid immigration documents that allow residence or visits (Ellis 2015). Ellis (2015) referred to undocumented and non-status individuals as irregular migrants, while Goldring et al. (2009) used nonbinary categories such as precarious legal status to describe what they call the 'array of gradations' that exists within legal and illegal statuses. Categories of (il)legality call into attention how the risk, uncertainty and persistent vulnerability that undocumented migrants experience are produced through legal and social processes (Villegas 2014). To move past binary and dehumanizing identity categories of legality/ illegality, we use the term non-status to intentionally account for the socio-political processes that shape migrants' everyday experiences of (in)access to state services (Ellis 2015). Thus, non-status migrants refer to both persons who are in Canada without immigration status and without the ability 
to access health and social provision within their place of residence.

According to migration scholars, most non-status migrants in Canada enter through legal channels (Bhuyan et al. 2016; Bonifacio 2017; Kamal \& Killian 2015). An estimated $95 \%$ have entered through the Temporary Foreign Worker Program (TFWP) and have thereafter overstayed their permits (Ellis 2015). The remaining 5\% are refused refugee or sponsorship claimants and former holders of expired student or visitor visas. Refused claimants are often deemed ineligible for status because of complex and constantly changing im/migration programs and eligibility criteria (Ellis 2015; Magalhaes et al. 2010). Despite being denied stay, non-status migrants have made the intentional decision to remain in Canada. Though the exact number of non-status migrants is difficult to measure, researchers have reported that there are approximately 20,000 to 500,000 living in or in close proximity to Canada's three major cities of Toronto, Montreal and Vancouver (Ellis 2015; Foster \& Luciano 2020; Meloni et al. 2014).

\section{Literature Review}

Critical scholarship on the settler-nationhood of Canada points to the historic and enduring need of racialised immigrants and migrants to build and bolster the economy through the secondary and tertiary labour market (Block 2011; Sharma 2006). Scholars have noted that current migration programs systematically exploit vulnerable migrants and their aspiration/desperation to stay in Canada by offering jobs that are significantly undercompensated and/or characterised by inhumane labour conditions (Ellis, 2015; Magalhaes et al. 2010; Sharma 2006). Research on foreign domestic workers, for instance, underscores how racialised women from the Global South are at risk for physical, emotional and economic abuses due to their precarious and unsecure residency status (Banerjee et al. 2018; de Leon 2018). Foreign domestic workers, who in the past were required to live with their employers, were forced to accept these labour conditions in order to apply for permanent residency (Alcuitas et al. 1997; de Leon 2018). Despite meeting labour and residency requirements, domestic workers were not guaranteed to receive permanent residency status, rendering the threat of deportation constant.

According to Miklavcic (2011), a non-status person is essentially a nonperson because without legitimised residency or migration status, they have few legal rights and are ineligible to receive most formal social and health services provided to Canadian citizens and permanent residents. These services include education, health, social welfare, housing, immigration, legal, and emergency services. In addition to denied services, non-status migrants face the constant threat of deportation and live their lives in hiding (Basok et al. 2014; Nyers 2010). As such, non-status migrants are considered to be a marginalised and oppressed population whose access to human rights are continually denied, and life experiences are shaped and structured by programs and laws that forefront and valorise their (in)visible labour contributions (Ellis 2015).

\section{Living and Working Conditions in the Peripheral (Underground) Economy}

While in hiding, non-status migrants are often able to survive and provide for families in their homeland by working in low-wage jobs in the secondary and tertiary labour markets and sending their earnings home through remittances (Magalhaes et al. 2010). This work is considered ostensibly unskilled, menial, high-risk, seasonal and/or temporary within the fields of construction, hospitality, agriculture, manufacturing and domestic work (Marks 2013; Sharma 2006). Basok et al. (2014) characterised this work as the four ' $D$ ' jobs (dirty, dangerous, difficult and demeaning) where employment statuses are unrecorded. Moreover, nonstatus migrants are unable to pursue and receive workers' compensation and/or disability benefits in the event of illness or workplace injuries. Not only do non-status migrants experience job insecurity and precarity, they have limited or non-existent recourse to challenge their employers for unjust working conditions (Ellis 2015; Marks 2013; Villegas 2017). Given these significant power imbalances, scholars have highlighted how employers generally exploit non-status migrants' vulnerability and desperation for work opportunities where few employers have been successfully prosecuted for hiring or abusing non-status people (Ellis 2015).

\section{Impact on Physical and Mental Health}

The immense mental health impact of living without status in Canada is both immeasurable and pervasive (Magalhaes et al. 2010). Existing literature on non-status work highlight how non-status migrants are at a higher risk of contracting diseases and injuries because of high-risk and exploitative work, lack of access to healthcare services and medications and language barriers (Campbell et al. 2014; Magalhaes et al. 2010). Further, given the precarity of their status, many are apprehensive to report medical emergencies or attend preventive check-ups for fear of detection or deportation (Campbell et al. 2014). While the existing scholarship underscores the inequities endured by non-status migrants vis-à-vis health and social services, there is a paucity of studies that examine these challenges in Canada. Therefore, limited information is available about how they experience precarity while at the same time, fulfilling caring responsibilities locally and transnationally to family members, and 
navigate work, housing and other pertinent issues of survival (Kamal \& Killian 2015). More recently, Tungohan (2020) adopted a multi-scalar intersectional analysis to examine the settlement, separation and formation of new families as Filipino migrants oscillate between their temporary statuses in search of permanent residency in Canada.

In an attempt to address the lack of non-status migrant voices, this article presents a small-scale case study examining the experiences of five non-status migrants living in Alberta. We employ a case-study approach to closely examine the intricate details from the participants' perspectives via multiple sources of data (e.g. interviews, policy analysis, discourse analysis) (Yin 2011). The primary research question for this study was: What are the experiences of non-status persons in Calgary in accessing social, health and other community services? Additional questions included: What are the specific needs of non-status people, and what resources or services do non-status migrants most often obtain?

\section{Theoretical Approach}

Our study was informed by theories that explicate the interconnections between labour, migration and global capitalism (de Leon 2018; Francisco-Menchavez 2018; Rodriguez 2010). While the classic paradigm probing the migration/ economic nexus are push-pull theories that frame labour flow as an outcome of dialectical push factors (such as economic, social and political hardships within labour sending nation-states) and pull factors (such as comparative advantages in privileged nation-states) (Borjas 1989), theorists have critiqued these perspectives for their limited account of the social and historical causes of immigration. Portes and Borocz (1989) suggest that international labour migration is better understood as a social phenomenon where networks are constructed by the movement and contact of people across space. Castles and Miller (2003) suggest that the term transmigrant may be used to identify people whose experiences are shaped by their participation in migration and the creation of transnational communities. One of the ways in which globalisation and neoliberalisation have transformed migration flows and the formation of transnational communities is through the restructuring of the nation-state's willingness to engage in what Robyn Rodriguez (2010) calls labour brokerage. Using the Philippines as a case example, Rodriguez (2010) asserts that the Filipino nation-state has a legacy of colonial submission and 'benevolent assimilation' as colonial subjects. This identity has allowed the state to negotiate with labour-receiving states to:

"formalize outflows of migrant workers and thereby enable employers around the globe to avail themselves of temporary workers who can be summoned to work for finite periods of time and then returned to their homeland at the conclusion of their employment contracts" (Rodriguez 2010, p. x).

Introduced since the Marcos years, this labour brokerage system allows the state to systematically deploy exported labour for profit from migrants' remittances. Since the 1980s and 1990s, the remittances of overseas foreign workers (OFW) workers kept the Philippines afloat and had effectively re-conceptualised and valorised labourers as 'modern-day heroes' (De Guzman 1993; Rodriguez 2010). Rodriguez (2010) argues that the labour brokerage system functions to address failures of development and has come to represent the neoliberal technology of governmentality, allowing the market to dictate the flows of labour migration, giving rise to the restructuring of labour markets and the reorganisation of work based on creating and fulfilling structural demands for foreign, temporary and so-called lowskilled migrant workers. We draw on Rodriguez's (2010) seminal work on labour brokerage to acknowledge the dual market or division of labour where international migration is believed to stem from the intrinsic labour demands of modern industrial societies. Building on a Marxist understanding of wage-labour to further the gains of the private ownership class, expendable and racialised migrant labour enhances the transnational capitalist scheme by further reducing the costs (exchanges) of wage-labour and enhancing precarity in order to eradicate collective organizing or bargaining rights. Thus, the intersections of transnational capitalism and migration as a form of state-sanctioned labour brokerage frame this study.

\section{The Temporary Foreign Worker Program in Canada: Elusive Dreams of Moving From Temporary to Permanent}

Migration scholarship and the concept of the labour brokerage state are helpful in understanding the formation and maintenance of migration programs in settler-societies such as Canada. The Temporary Foreign Worker Program, first introduced in 1973 as a mechanism to hire foreign nationals in Canada, was expanded in 2002 by streamlining the hiring of what was characterised as 'low-skilled' labour. Despite being labelled 'low-skilled', many TFW workers and in particular foreign caregivers, are professionals back in their home countries and possess post-secondary education (Francisco-Menchavez 2018). The TFWP has since been emblematic of the Canadian immigration regime, whose characteristics have transitioned from permanence to perpetual temporariness (Bonifacio 2017; Ellis 2015; Tungohan 2018). While the TFWP is 'designed to help employers fill short-term gaps when qualified Canadian citizens or permanent residents are not available' (Government of Canada 
2012), in practice, it became an effective tool for employers to hire temporary foreign workers (TFWs) from underdeveloped countries who are desperate to alleviate poverty for themselves and their communities. The meagre earnings of migrant workers compared with typical Canadian workers are considerably higher when compared with the converted income in their home countries.

Since 2000, the number of TFWs in Canada has quadrupled with more than 310,000 work-permit holders (Government of Canada 2017). Under the TFWP, workers are bound to a single employer and undergo a rigorous, bureaucratic and costly process to change employers, leading some to return to their home countries. Scholars and advocacy organisations emphasise that the restrictions imposed on TFWs violate Article 6 of the International Covenant on Economic, Social and Cultural Rights, which guarantees the right to freely choose or accept work, and to full and productive employment in conditions which safeguard political and economic freedoms (UNESCO 2017). Moreover, advocacy organisations and media have exposed workplace abuses, and the impunity granted to employers who negate their responsibility to provide social and health services and respect human rights. Responding to a growing outcry regarding these violations, the Canadian government implemented a cumulative-duration rule in 2011 (colloquially known as the '4-in-4-out rule'), which limited how long TFWs could stay in Canada. More recently, the federal government scrapped the 4-in-4-out rule, acknowledging and prioritizing the need for a free flow of labour migration through the TFWP (Canadian Citizenship \& Immigration Resource Center 2016).

\section{Emergence of the Filipino Community through Racialised Migration Programs}

Filipino-Canadian scholars have highlighted the intergenerational impacts of migration and labour programs caused by the structural barriers on multi-generational Filipino families. Over the last 10 years, scholarship has highlighted the structural barriers of the TFWP, and its intergenerational impact on multi-generational families, particularly for Filipino workers and families who represent the largest proportion of TFWs. In Coloma et al.'s (2012) seminal book, Filipinos in Canada: Disturbing Invisibility, McElhinny, Davidson, Catungal, Tungohan and Coloma (2012) call attention to the ways in which Filipino/as entering through migration and labour programs find themselves within the paradoxical position of being invisible and hyper-invisible due to their emerging presence within urban and rural settings. Despite the emergence of Filipino communities across Canada, issues of their most precarious members are taken for granted and/or ignored by the broader Canadian society.
In $2019,10,100$ newly arrived TFWs originated from the Philippines (Statista 2020). Bonifacio $(2013,2017)$ offers a comprehensive assessment of Filipinos who chose settlement within Western, and particularly Prairies, provinces of Manitoba, Saskatchewan and Alberta. Within the Prairies, TFW workers have become an important part of the labour market, where according to Foster and Luciano (2020), the number of TFWs has more than quadrupled to almost 400,000 within the last 12 years; with 77,000 migrant workers living in the province of Alberta. Despite the growing awareness of workplace abuses, there is still a lack of protection for TFWs who experience poor workplace conditions (Bhuyan et al. 2016; Bryan, 2018). Coupled with their indentured immigration status, persistent issues of abuse and the lack of labour protection have led many TFW participants to contend with these stark realities as they settle in Canada. The process of migration for TFW workers and the ultimate objective of going from temporary to permanence is wrought with bureaucratic challenges (Tungohan 2017), which often leads to undocumented stays or what Filipinos have colloquially termed tago ng tago or TNT (Filipino translation: always hiding). Figure 1 offers an overview of the process that workers must follow to receive permanent residency.

\section{Methodology and Research Design}

Given the proportion of TFWs coming to Canada from the Philippines, we would like to intentionally situate ourselves as authors and disclose our personal and professional connections to the work we do with non-status people. As a writing team, we represent first (Alcaraz), 1.5 (Ferrer), second (Abes)-generation Filipinos and allies to TFWs (Lorenzetti), who are actively engaged in social justice advocacy, grassroots community organizing and scholar-activism. Some of us have direct experience in activism, worked as TFWs, and conducted community-based research and capacity building within academic and community spaces. First author, Nellie Alcaraz, migrated to Canada through the Live-in-Caregiver Program, a precursor to the current Caregiver Program, and a current subset of the TFWP. Inherent to the TFWP, Alcaraz experienced workplace abuses and has centred herself in migrant justice activism for more than a decade. As a member of Migrante Alberta, she was actively involved in the McKenna Rose campaign that successfully lobbied the Alberta government to grant children of non-status migrant eligibility and access to care and services under the Alberta Health Care Insurance Plan (Pinoy Edmonton News 2017).

Rooting our experiences within a theoretical framework that articulates the intersections of migration, labour brokerage and transnational capitalism, this study draws from a case-study led by the first author and funded by MITACS. 


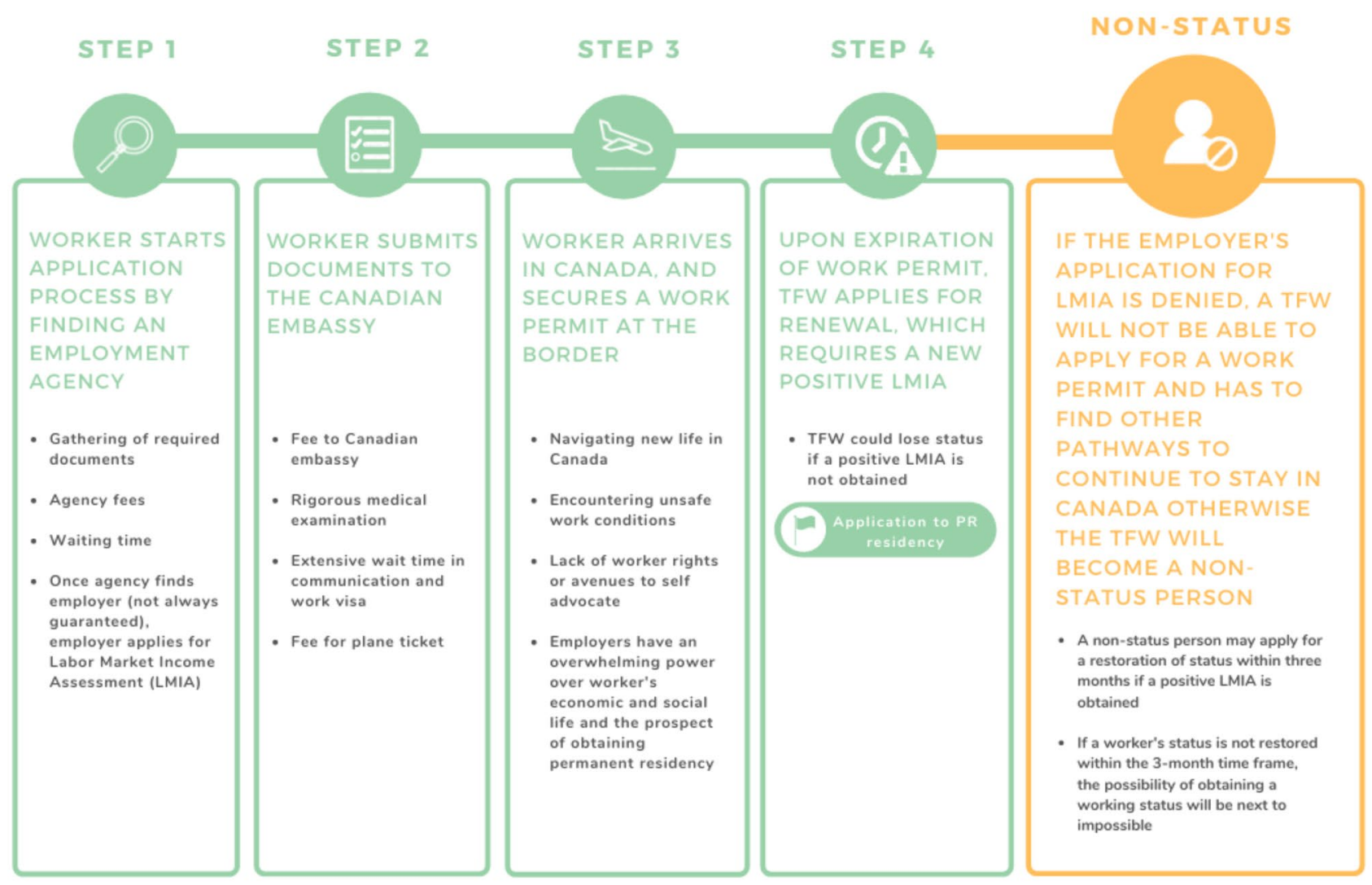

Fig. 1 Process of migration: from temporary to permanence to non-status

Our small-scale study adopted a case-study approach, which examines 'detailed, in-depth data collection from multiple sources of information and [reports] a case description and case-based themes' (Creswell 2007, p. 73). Our data collection included interviews with five non-status individuals who migrated to Canada under the TFWP. Our study also employed narrative inquiry as a way to highlight and make sense of people's lived experiences (Josselson \& Lieblich 1996; Lieblich et al. 1998), forms of communication (Fisher 1984) and the interplay of individual and social, cultural and discoursal factors (Frank 1998; Plummer 1995). Combining narrative inquiry with critical reflection provided a 'framework for deconstructing the stories and exploring assumptions about knowledge, power and reflexivity' (Hickson 2016, p. 386). Drawing on Bamberg's (2010) work on narrative identity and 'dilemmatic spaces', the interview transcripts were analysed in view of how participants reflect on and navigate their identities and spaces through everyday lived experiences as well as broader processes of transnational migration (including identity formation in the contexts of local environment, race, gender, nationalism, citizenship and conflicts).

Our data collection included a scoping and policy review on the TFWP in Canada. Consistent with a case-study design, the objective of our study was to provide 'an empirical inquiry that investigates a contemporary phenomenon within its real-life context, especially when the boundaries between phenomenon and context are not clearly evident' (Yin 1994, p. 13). This research received ethics approval from the University of Calgary's Conjoint Faculties Research Ethics Board where all participants provided their informed consent.

\section{Recruitment and Procedures}

Participants were recruited through snowball sampling with members of Migrante Alberta, the key partner in this study. Founded in 2013, Migrante Alberta is an advocacy organisation and is a branch of Migrante Canada, an alliance of twenty Filipino migrant organisations across Canada (Migrantealberta, n.d.). As an organisation, Migrante Alberta is well-situated in advocating for the rights and welfare of migrant and non-status workers. Although an active member of Migrante Alberta, the first author did not engage with the recruitment process. Rather, other members of Migrante Alberta circulated the recruitment letter to potential participants. Interested participants then communicated directly with the first author. Audio-recorded individual 
interviews were conducted by the first author in October to December 2018 with the five individuals who were living in the city of Calgary, Alberta. Non-status participants received an honorarium in recognition of and commensurate to their time and labour. In line with our research team's commitment to support non-status migrants and to engage in reciprocal relationships, participants were involved in all aspects of the study including member checking of transcripts and analysis. Finally, the first author also engaged in an intentional knowledge mobilisation plan with Migrante Alberta and participants to ensure that their stories were accurately reflected and positioned to generate discussion on policy change. Examples of knowledge mobilisation activities included a literature review for community use, a policy brief and sharing of resources not previously known to nonstatus migrants and their networks.

\section{Findings}

Our findings highlight five case-based themes that centre on (1) the undocumented costs of striving for status, (2) aspirations to stay in Canada, (3) navigating through the everyday struggles of survival, (4) acts of selflessness and (5) resistance against the stigmatisation of being a non-status migrant. Rather than present each theme in aggregate, we offer our main case-based themes in ways that specifically situate the narratives of our participants within the process of being a documented migrant to a non-status migrant (see Fig. 1).

\section{MJ's Story and the Undocumented Costs of Striving for Status}

MJ came to Canada in 2013 to work as a food attendant under the TFW program after working for years as a factory worker in Taiwan. Prior to arriving in Canada, MJ paid $\$ 5000 \mathrm{CAD}$ to a third-party recruiter in Taiwan to broker her labour market assessment (LMIA). Although MJ signed an agreement to work for a restaurant chain in Calgary, she soon discovered that her recruiter did not broker a job, nor did she have an employer. MJ explains her situation as such:

"Yes [we were all from] Taiwan. We got separated... because our [third-party recruiter did] not try to find [us work]. [W] did not [expect] that we will not have work because [our recruiter] said he has a restaurant. ... We were supposed to make a complain[t] but we got scared."-MJ.

After 6 months, MJ was able to secure a work permit at a fast-food restaurant chain. However, this work did not last long due to her employer's bankruptcy. MJ explains, 'the restaurant was sold. [My new employers] applied for LMIA but it was denied then the employer just sold [their restaurant]. The money we paid was wasted'. MJ would recount how she bounced from contract to contract from 2014 until 2016, working in various service sector jobs while shouldering extensive costs of applying and re-applying for LMIA assessments:

"What happened was I went to [another recruiter]. He [was supposed to arrange a new] LMIA...[but] I ran out of time. [The recruiter] did not even apply for anything; not even for visitor's [visa] or something. I paid him $\$ 1000$ CAD. That was for [a] LMIA, but it was not done because my boss could not provide the tax. ... I eventually lost my status [as a TFW]."-MJ.

Although MJ would apply for a visitor's visa and other work permits to prolong her stay in Canada, all of her applications were denied. MJ's story highlights the extensive financial costs that she, and other participants, incurred to come and remain in Canada. Her experiences also render salient the risks of trusting third-party brokers and recruiters, who are unregulated and are not accountable for errors, misconduct or undelivered services. In particular, MJ's story accentuates how TFWs who initially entered Canada through official channels might feel compelled to go into tago $\mathrm{ng}$ tago. For MJ and the four other participants in this study, they had trusted their brokers to render services in finding employment. Yet, after receiving 'fees', these agents often neglected their client's LMIA and work applications. Amidst her struggle to find work/permits to legitimatise her stay in Canada, MJ met her partner who was also a non-status migrant. They married in 2018 and had their first child a year later. MJ shares with us the financial stress in not having status or jobs while being pregnant. For instance, MJ was required to pay for most of her medical check-ups and did not receive adequate maternal care during and after her pregnancy. She explains, 'there was no [service]. Right now, I can't find a family doctor because they might not accept us. There might be no hospital here that will take me'. Despite the emotional toll she and her family has faced, MJ still perseveres and hopes to receive a legitimate work permit in hopes of a better future for her daughter.

\section{Maria's Story and Multi-generational Aspirations to Stay in Canada}

Maria shares a similar migration and labour story as MJ. After working in Taiwan as a factory worker, Maria migrated to Canada in 2012 where she gave birth to two children within a 2-year period. After paying a broker agency $\$ 4090.75$ CAD to process migration papers, Maria was hopeful to establish a life with her young family. However, her work permit expired in 2014. She tried many pathways, 
paid consultants and lawyers to restore her immigration status but met multiple barriers. Maria attributes her entry into non-status to unethical and 'dodgy immigration consultants' whom she trusted and heavily compensated.

"I asked: how do we survive? The consultant responded I just have to have a business. So I established a cleaning business because he told me to have a business and register it to my child so that it's not directly [tied to my name]".--Maria.

Since losing her status, Maria began cleaning houses to support herself and her two children. While anxious of facing possible legal ramifications and deportation, she also shares her aspiration to stay in Canada to support her young children. Here, Maria juxtaposes her children's education in Canada with the scarcity of resources in the Philippines:

"[Back home there is] no hospital. ...Then second: no job. You can work if you have land [but]almost all of us... are roaming in Dubai [and] Saudi [Arabia]. [We do it] just to get [our] kids to school".--Maria.

Even if it is emotionally difficult, the social and economic conditions in the Philippines offer motivation for non-status workers to remain in Canada. The physical and financial sacrifices made just to arrive and subsequently work in Canada are testaments of Maria and her family's desire to permanently settle. Maria describes her harrowing struggle to not only pay for brokering agency fees but her financial responsibilities to send remittances to her family in the Philippines. On top of caring and providing for her children's' daily needs, who are Canadian (by birth), she worries that she could be repatriated to the Philippines at any time. With income and food insecurity a primary concern, Maria's situation leaves her in no condition for adequate financial planning.

\section{Shirley's Story and Navigating Through the Everyday Struggles for Survival}

Like MJ and Maria, Shirley was a factory worker in Taiwan before arriving to Canada in 2014 as a TFW. Shirley paid $\$ 3000$ CAD to recruiting agencies in Taiwan, the Philippines and Canada. The following excerpt describes her situation:

"My situation here is complicated because when I came here in June 2014, I did not have a job because... my employer could not employ me. ...I still decided to come here because I had already spent an enormous amount towards my agency in Taiwan and in the Philippines. ...I took the chance of whatever my fate... would be. ...I think all of us have dreamed of coming to Canada. ...I spent so much already, and so I really pushed myself to come here. I was taking my chance that if I come here, I will find a new employer[and] I will be able to fix my papers and so I gambled and [took] my chance. ...[It's an opportunity that] does not come often".--Shirley.

Shirley and her partner both lost their status in 2016 when she was 3 months pregnant with her first child. Despite paying $\$ 11,000$ CAD to immigration consultants who promised to process her status papers, all of Shirley's applications were denied. To make matters worse, Shirley's husband was deported, leaving her to deliver her child on her own. Without her husband, Shirley felt significant stress, describing her situation as physically exhausting and emotionally depressing. She expresses the sadness of bearing her child alone and potentially '[giving] up [her] dream of living in Canada to provide a good life to [her] child'. Yet, despite being alone, Shirley believes that a life in Canada is much better than raising her child in the Philippines alongside her husband. This decision, however, came at a heavy financial cost. Shortly after giving birth, Shirley received a bill from Alberta Health Services for $\$ 7000$ CAD. A few weeks later, she was hospitalised again for a ruptured appendix and was given a total medical bill of $\$ 50,000 \mathrm{CAD}$.

"It was very frustrating. ...It was not just stressful [and] emotional depression that I felt [but] physical exhaustion. ... Especially when my husband went back home when I was pregnant here and without papers. It was very difficult. What people like myself are going through is not easy. ...So I decided to stay here and take my chance, because at that time the agency [was] still trying to apply for my husband to come back here".-Shirley.

The typical reaction of most Canadians is that when migrants break the law, they should be deported to their home country. This societal perception had a significant impact on Shirley's mental health. In the following excerpt, she shares the everyday impact of living in fear:

"You feel every time you go out, you are like a criminal, and that the police [will catch] you. ...[If] you do not have papers, you are always fearful... that they will send you home... [or] that you might go to prison".-Shirley.

Shirley, like all five participants, experiences the social isolation resulting from fear of deportation. Despite developing bonds of friendship with roommates, Shirley reminds us that, 'One day I [might] just hear knocks on our door asking us to go home'. Shirley also shares how she continued to be hopeful in her situation. She states, 
"There are people from the community like Migrante Alberta [who] actually helped... If not for [them] I will not have this strength right now. It's the support that [they] gave me not just for everyday needs but also emotional and even spiritual needs as a human being. It is a huge thing for me to survive every day".

\section{Nancy's Story and Acts of Selflessness}

Nancy came to Canada under the former Live-in Caregiver Program (LCP) in 2009. After her contract was completed, Nancy applied for permanent residency but was denied because her application included the sponsorship of her daughter from the Philippines. Nancy was then granted another work permit and would once again apply for permanent residency in 2018. Her application was denied a second time because of her daughter's 'medical inadmissibility', a stipulation within most Canadian immigration programs that rejects applicants who are considered an excessive burden to the health care system. Nancy was told that her application could be accepted if she could prove possession of $\$ 100,000$ CAD in her bank. She explains her situation as follows:

"My child...has impaired hearing. She had hearing loss since she was four years old. That's why...I need to provide 100 thousand [Canadian dollars]. Where would I get that?...[The government] said I need... funds in my account in that amount. ...For my child, if ever she arrives here... she will not ask help from the government. ...I never dreamed to ask any support from the government".- Nancy.

At the time of the interview, Nancy was waiting for Immigration, Refugees and Citizenship Canada's (IRCC) decision on her third permanent residency application. Due to her previous experiences, she made the difficult choice to leave her daughter out of her application. Nancy's situation highlights a common struggle and self-sacrifice for the sake of families in the Philippines. The profiles of all five participants suggest that each has either younger children or members of their family requiring immediate caregiver attention and ongoing support. Nancy explains the very difficult decision of intentionally withholding sponsorship of her daughter to avoid a third application rejection. Nancy discloses that she is losing her sanity because her work barriers are too significant and cannot be overcome with willpower alone. Whenever Nancy would find employment, she would be subjected to workplace abuse. Nancy's employers would often use her non-status work permit as leverage to terminate her employment; thus, leaving Nancy with no choice but to endure precarious conditions to earn money, provide for herself and her family in the Philippines and ultimately support her dream of Canadian residency. When asked about how she manages to persevere, Nancy expresses that no matter what happens, she refuses to give up because of her child. Finally, Nancy discusses the unfairness of spending a fortune to work in Canada and secure the necessary documents for migration only to receive substandard wages and workplace abuses. She reflects on the contributions that TFW workers and non-status migrants make to Canadian society:

"We pay tax. ...[We] have done nothing wrong. While here, [the employer] pays what they really want to pay [us]. [We] can go home if [we] do something they don't like. ...Very unfair".-—Nancy.

\section{Manuel's Story and the Resistance Against the Stigmatisation of Status}

Manuel came to Canada in 2009 under the TFWP after paying P200,000 (Philippine pesos) or the equivalent of $\$ 5565$ Canadian dollars to broker an employment contract. After 4 years of work as a vegetable packer in Ontario, Manuel left for Alberta in 2012 where he would work in construction after applying for an additional work permit. Unfortunately, in 2015, Manuel was diagnosed with kidney failure. This would mark the start of Manuel's spiral decline to nonstatus, as his employers gave him the ultimatum of: 'work or go home'. He explains his situation as the following:

"The thing was... I contracted kidney illness here. ...

My employer told me, "you have to choose between

going home or staying here". I answered...my doctor

told me that because I got my illness here, I should

get treatment here. ...After that, I eventually lost my

job because all of my earnings went to the house-rent, food, [and] transportation like bus".-—Manuel.

One of our major findings is that non-status migrants strive earnestly to establish their lives in Canada despite their precarious status, and despite negative perceptions from the Canadian society. Our five participants spoke about being aware of dominant perceptions from the media and other Canadians-namely that non-status migrants are seen as taking jobs from Canadian workers, and that non-status people are exploiting the benefits of living within Canadian society. However, our undocumented participants spoke about their desire to abide by Canadian laws, including the financial and physical costs of their work. As Manuel discusses below, he has paid a significant toll working in Canada:

"I contributed to Canada and as soon as I arrived. I paid my dues. That's why they should have granted [me status]. They should give me a chance to have a family because I think that's what we deserve for [those of] us who made sacrifices". - Manuel. 
Manuel also points that nobody wants to be in their situation because 'it is difficult to be in constant hiding'. Shortly after his diagnosis, Manuel began the unsuccessful process of applying for permanent residency, knowing that employers would unlikely hire a worker with pre-existing health issues. After his work permits expired, Manuel remained in Canada and sought work within the peripheral labour market (colloquially known as 'under the table work' or 'underground work') to continue supporting his family in the Philippines. He explains, 'I want to give my family a better future. Unlike [in the Philippines], I am just a son of a peasant. ...We try to withstand it because we still want to live. We are still fighting'. Finding the balance between work and his illness was difficult to manage, Manuel was grateful that Migrante Alberta supported him financially, socially and emotionally. However, despite his ardent desire to stay in Canada, Manuel's health and physical condition worsened, impacting his weight and mobility. The emotional toll of being rejected for permanent residency, even on compassionate humanitarian grounds, was compounded by the physical separation from his family. Unable to work or access health and social services due to his lack of immigration status, Manuel fought for himself and relied on limited community supports. In 2019, after realizing he might not live much longer, Manuel stopped 'hiding' and returned to the Philippines. While Manuel was motivated to earn his Canadian permanent residency status, he could not bear the thought of dying without seeing his family.

\section{Discussion}

Non-status migrants continue to contribute to Canadian society even when they are forced into hiding. They contribute by directly participating in the labour force but do not directly benefit from the society that they help build (Nyers 2010; Ellis 2015). Our case study presented the stories of five non-status migrants who entered Canada legally, rigorously followed Canadian laws and policies, accepted the amount and type of work available to them, experienced abuses and exploitation and spent an inordinate amount of money in the hopes of obtaining a legal status. Unfortunately, the constantly shifting and narrow pathways to permanent residency and unregulated consultancy practices all contributed to their loss of status. These dynamics confirm what Goldring et al. (2009) calls the 'production of illegality', where immigration policies and social actors facilitate the (re)production of precarity to illegality. Stories shared by MJ, Nancy, Maria, Shirley and Manuel emphasise the precarity that non-status migrants face as they navigate and negotiate their non-status and desires for permanent residency. Moreover, their stories offer important counternarratives to the pervasive labour commodification and labour brokerage between Global North and South societies. The case-based themes selected from our study (undocumented costs of striving for status, aspirations to stay in Canada, navigating through the everyday struggles of survival, acts of selflessness and resistance against the stigmatisation of being a non-status migrant) were specifically identified by our participants to accentuate the structural barriers that impeded and ultimately blocked their pathways to permanent residency. When asked what messages participants wished to convey to policy makers and the broader Canadian society, they unanimously expressed their desires to see policy shifts so that their abuses would not be endured by others. In direct response to our participant's requests, we offer the following discussion linking their stories to specific policy and program recommendations.

\section{Status for All as Human Rights}

Section 7 of the Canadian Charter of Rights and Freedom (1982) states that 'everyone has the right to life, liberty and security of the person and the right not to be deprived thereof except in accordance with the principles of fundamental justice'. This seminal Canadian document also indicates that every individual regardless of residency or citizenship status is equal under the law and has the right to human dignity, respect, equality and justice (Canadian Charter of Rights and Freedoms 1982). Yet our participants' testimonials demonstrate how non-status migrants in Canada are unrecognised, invisible and effectively 'non-persons' (Miklavcic 2011). Our case study suggests that immigration status is a definitive and effective political and social tool that creates and reinforces perceptions of belonging and unbelonging. It defines who is deserving/undeserving of health and social services and even basic human rights such as food and shelter.x

Our findings build on existing research on undocumented workers, which show how non-status migrants have little to no access to healthcare, education, social services and legal rights (Magalhaes et al., 2010; Nyers 2010). As such, non-status migrants find themselves in untenable situations of precarity mainly due to their persistent fear of being reported and deported by immigration or border authorities at any given moment. The risks and impacts to physical and mental health caused by this legitimised precarity are exacerbated by the pervasive barriers to basic rights including provincially regulated minimum wage (Kamal \& Killian 2015; Villegas 2017). While Canada is a signatory to the United Nation's International Covenant on Economic, Social and Cultural Rights (UNESCO 2017), a document that recognises that the right to the highest attainable standard of health is indeed a human right, the federal and provincial governments continue to exclude individuals without immigration status from accessing health services 
(Campbell et al. 2014; Kamal \& Killian 2015; Magalhaes et al. 2010). As a high-income country, Canada undeniably owes its wealth to the economic contributions of racialised immigrants, migrants and non-status migrants, who have historically upheld and currently upholds the Canadian caring and labour economy but rarely benefits from it. This wealth contributes to maintaining a much-lauded universal healthcare system which excludes non-status migrants. The powerlessness and desperation of non-status migrants to stay in Canada makes them most vulnerable to exploitation, marginalisation and exclusion which then provides fertile ground for employers to underpay and continually uphold sub-standard, disposable and abusive labour practices.

The stories of the five non-status participants in this study underscore the importance of full and equitable access to Canadian healthcare and other financial or social services regardless of im/migration status. Manuel's story strongly represents how healthcare should be a basic human right for all. As with every TFW who came to Canada, Manuel had undergone and passed a rigorous medical inspection before he received his Canadian work visa. However, Manuel's health deteriorated after working in hazardous working conditions for 9 years. His illnesses compromised his migration status, and he was ultimately denied adequate and appropriate health and social services at a time of urgent need. His appalling living situation compelled him to seek life-support services from his financially strapped family in the Philippines. Had Manuel received adequate medical intervention, he could have continued to be a contributing member of Canadian society.

\section{Regulating Third-Party Brokers and Services}

The stories of our five participants showed the convoluted process of acquiring and failing to maintain legal status in Canada. This article contends that an overhaul of the TFWP is needed to ensure that migrant workers coming to Canada, especially those that are ostensibly considered to be low and semi-skilled labourers, do not fall into precarity. Moreover, in order to curb the unprecedented number of non-status individuals in Canada, temporary migrant workers that fill permanent labour needs should arrive as permanent residents. At the very least, migrant workers should be given an open work permit valid for an extended period of time to ensure that workers are mobile and able to uphold their right to collective bargaining. Finally, given the complicated process of applying for status, our participants spoke about the need for a state agency to assist workers looking to transition from temporary to permanent residency.

The desire to stay and potentially build a life in Canada was a common narrative of our five participants, who all paid exorbitant agency fees and fell prey to fraudulent immigration consultants. Immigration consultants, who are sometimes from the communities they are serving, are effectively profiting from the desperation of Filipino TFWs looking to permanently settle in Canadian society. In situations such as Nancy, who paid a heavy emotional and financial toll in her attempt to bring her daughter to Canada, misinformation about migration and permanent residency rules shows the need for stricter state regulations on consultant practices (Foster \& Luciano 2020). While it can be argued that TFWs understand the nature of the migration process and eligibility criteria surrounding their status, there are significant power imbalances between TFW applicants and immigration consultants. This paper recommends that federal and provincial governments need to follow through on campaigns to regulate and mandate fee guidelines for licensed immigration consultants, and to cap the amount that consultants charge their clients. The Immigration Consultants of Canada Regulatory Council (ICCRC) is a regulatory body established to promote and protect public interest by overseeing the work being done by consultants. However, the ICCRC 'does not currently have the authority to pursue unlicensed immigration consultants but [does direct] complaints to the Royal Canadian Mounted Police (RCMP) and Canada Border Services Agency (CBSA)' (Immigration Consulants of Canada Regulatory Council n.d). Recently, the ICCRC has announced its transition to become The College of Immigration of Citizenship, where it will have the 'authority to file an injunction against a person who acts as an unlicensed immigration consultant and to engage directly with foreign government agencies' (Immigration Consultants of Canada Regulatory Council n.d.). Regulatory bodies that oversee and surveillance the practices of immigration consultants are crucial in preventing workers, who are deemed essential to the Canadian society, from falling into precarity, exploitation and abuse.

\section{Non-Status in a Time of COVID-19}

At the time of writing, the world has experienced the unprecedented worldwide pandemic of COVID-19 (Migrant Rights Network 2020). As mass unemployment began to spread across Canada, TFWs were the first to feel the brunt, as many did not have economic stability to withstand the sudden loss of employment and employment opportunities (CBC News 2020; Chronicle Herald 2020; Rivera 2020). While state officials, media and society have been quick to recognise healthcare and frontline workers, it is the unheralded work of essential workers (particularly TFWs) within meat-packing plants, agricultural sector, in the fast-food industries and grocery stores that have ensured the survival of the global supply chain. These workers are mostly people from the Global South, particularly from the Philippines, Mexico and the Caribbean, who Rodriguez (2010) called 'migrants for exports'. While state officials have acknowledged these workers as essential, politicians continue to pathologise 
the spread of the disease onto migrant communities while neglecting pressing issues of residency and employer abuse. COVID-19 outbreaks within the Cargill, JBS and Harmony Meat Packing plants in Alberta underscore how the global supply chain is more important than the safety and wellbeing of workers (Cala 2020; Migrant Rights Network 2020).

Reality is stark for non-status migrants who experience the same challenges as status labour migrants, but also insurmountable barriers and stigma of living tago ng tago. The advent of the pandemic deepened the precarity of temporary foreign workers, as they were not initially eligible to receive support through Employment Insurance or emergency funding initiatives. Only once temporary migrants were deemed integral to ensuring the viability of the supply chain did the state include and facilitate stays of TFWs. Even through COVID-19, the plight of non-status people remains unchanged. Such dynamics underscore the constant disposability of TFWs, and the urgency to rethink how migrants are granted status while in Canada.

Acknowledgements We would like to thank our five participants who generously and courageously shared their stories with us. We also thank Migrante Alberta for their ongoing support and advocacy towards nonstatus migrants. We acknowledge the contributions of Kristiana Cruz, who graphically designed our figure. Finally this manuscript is dedicated to all migrants who have (and have been) forcibly displaced from their homelands. We honour the memory of Alfredo Aguilar, Jr.

Author Contribution The primary author was responsible for interviewing, coding, analysing, writing and editing the manuscript. Coauthors contributed to the research design, writing, analysis and edits on the manuscript's content and structure.

Funding This study was funded by Mitacs Accelerate Project \#IT12281.

Data Availability Qualitative data was collected using a digital recorder, and subsequently transcribed with names and identifying information redacted and changed for confidentiality purposes. Transcripts were stored and encrypted for security purposes.

\section{Declarations}

Conflict of Interest The authors declare that they have no conflict of interest.

\section{References}

Alcuitas, H., Alcuitas-Imperial, L., Diocson, C., \& Ordinario, J. (1997). Trapped: holding on to the knifes edge: economic violence against Filipino migrant/immigrant women Vancouver, BC : The Feminist Research. Education.

Bamberg, M. (2010). Who am I? Narration and its contribution to self and identity. Theory \& Psychology, 21(1), 3-24.

Banerjee, E., Kelly, P., Tungohan, E., Cleto, P., de Leon, C., Garcia, M., Luciano, M., Palmaria, C., \& Sorio, C. (2018). From migrant to citizen: labor market integration of former live-in caregivers in Canada. ILR Review, 71(4), 908-936.

Basok, T., Belanger, D., \& Rivas, E. (2014). Reproducing deportability: migrant agricultural workers in South-western Ontario. Journal of Ethnic and Migration Studies, 40(9), 1394-1413.

Block, S. (2011). Canada's colour coded labour market the gap for racialized workers (G.-E. Galabuzi, C. C. for P. Alternatives, \& W. Institute, eds.). Ottawa, Ont.: Ottawa, Ont. : Canadian Centre for Policy Alternatives $=$ Centre canadien de politiques alternatives : Wellesley Institute.

Bonifacio, G. T. (2013). Pinay on the Prairies. UBC Press.

Bonifacio, G. T. (2017). (Mis)Givings in a prairie city? Identity and belonging of Filipina (Im)migrants in Lethbridge, Alberta. In G. T. Bonifacio \& J. Drolet (Eds.), Canadian Perspectives on Immigration in Small Cities (pp. 77-98). Springer International Publishing.

Bhuyan, R., Osborne, B. J., \& Cruz, J. F. J. (2016). Once you arrive, Se Te Sala Todo (everything is salted): Latina migrants' search for dignity and a right to life in Canada. Journal of Immigrant \& Refugee Studies, 14(4), 411-431.

Borjas, G. J. (1989). Economic theory and international migration. The International Migration Review, 23(3), 457.

Bryan, C. (2018). Wait and While you Wait, Work: On the reproduction of precariuos labour in liminal spaces. In P Gardiner Barber \& W. Lem (Eds.) Migration, Temporality, and Capitalism (pp. 123-139). London, UK: Palgrave Macmillan.

Cala, C. (2020, May 23). COVID-19 crisis is unmasking racial inequities. Edmonton Journal. https://edmontonjournal.com/opinion/columnists/ opinion-covid-19-crisis-is-unmasking-racial-inequities/wcm/ d101a6d6-b4bf-48e9-84c4-812f2451def5/

Castles, S., \& Miller, M. J. (2003). The age of migration: international population movements in the modern world (3rd ed.). Guilford Press.

Campbell, R., Klei, A., Hodges, B., Fisman, D., \& Kitto, S. (2014). A comparison of health access between permanent residents, undocumented immigrants and refugee claimants in Toronto, Canada. Journal of Immigrant and Minority Health, 16(1), 165-176.

Canadian Charter of Rights and Freedoms. (1982). s8, Part 1 of the Constitution Act, 1982, being Schedule B to the Canada Act (UK), c 11.

Canadian Citizenship \& Immigration Resource Center. (2016). Temporary foreign worker program: four-in, four-out rule abolished. Retrieved May 16, 2020, from https://www.immigration.ca/ temporary-foreign-worker-program-four-four-rule-abolished/

CBC News. (2020). Overrepresented in service jobs, Filipinos more likely to have lost work in pandemic. https://www.cbc.ca/news/ canada/manitoba/filipinos-winnipeg-over-represented-servicejobs-lost-hours- 1.5723315

Chronicle Herald. (2020). Pandemic 'hero' Filipino nurses struggle to leave home. https://www.thechronicleherald.ca/news/world/ pandemic-hero-filipino-nurses-struggle-to-leave-home-497723/

Coloma, R. S., McElhinny, B., Tungohan, E., Catungal, J. P., \& Davidson, L. (Eds.). (2012). Filipinos in Canada: Disturbing invisibility. Toronto: University of Toronto Press.

Creswell, J. W. (2007). Qualitative inquiry and research design: choosing among five traditions. Sage Publications.

De Guzman, A. F. (1993). Katas ng Saudi: the work and life situation of the Filipino contract workers in Saudi Arabia. Philippine Social Sciences Review, 51, 1-4.

de Leon, C. (2018). Pagod, Dugo, Pawis (exhaustion, blood, sweat): transnational practices of care and emotional labor among Filipino kin networks. [Doctoral dissertation, York University]. ProQuest Dissertations and Theses Global.

Ellis, B. (2015). The production of irregular migration in Canada. Canadian Ethnic Studies, 47(2), 93-112. 
Fisher, W. R. (1984). Narration as a human communication paradigm: the case of public moral argument. Communications Monographs, $51(1), 1-22$.

Foster, J., \& Luciano, M. (2020). In the shawdows: living and working without status in Alberta. Parkland Institute.

Francisco-Menchavez, V. (2018). The labour of care: Filipina migrants and transitional families in the digital age. University of Illinois Press.

Frank, A. W. (1998). Just listening: narrative and deep illness. Families Systems \& Health, 16(3), 197-212.

Goldring, L., Berinstein, C., \& Bernhard, J. K. (2009). Institutionalizing precarious migratory status in Canada. Citizenship studies, 13(3), 239-265.

Government of Canada. (2017). Census Profile, 2016 Census: Alberta [Province] and Canada [Country]. Retrieved May 16, from https:// www12.statcan.gc.ca/census-recensement/2016/dp-pd/prof/index. cfm? Lang=E

Government of Canada. (2012). Fact sheet - temporary foreign worker program. Retrived May 16, 2020 from https://www.canada.ca/ en/immigration-refugees-citizenship/corporate/publicationsmanuals/fact-sheet-temporary-foreign-worker-program.html

Hickson, H. (2016). Becoming a critical narrativist: using critical reflection and narrative inquiry as research methodology. Qualitative Social Work, 15(3), 380-391.

Immigration Consultants of Canada Regulatory Council. (n.d.) Fraud prevention. https://iccrc-crcic.ca/fraud-prevention/

Josselson, R., \& Lieblich, A. (1996). Fettering the mind in the name of 'science'. American Psychologist, 51(6), 651.

Kamal, F., \& Killian, K. (2015). Invisible lives and hidden realities of undocumented youth. Refuge, 31(2), 63.

Lieblich, A., Tuval-Mashiach, R., \& Zilber, T. (1998). Narrative research: reading, analysis, and interpretation. Sage Publications.

Magalhaes, L., Carrasco, C., \& Gastaldo, D. (2010). Undocumented migrants in Canada: a scope literature review on health, access to services, and working conditions. Journal of Immigrant and Minority Health, 12(1), 132-151.

Marks, J. H. (2013). The undocumented unwell. Hastings Center Report, 43(1), 10-11.

McElhinny, B., Davidson, L. M., Catungal, J. P. C., Tungohan, E., \& Coloma, R. S. (2012). 1. Spectres of (In) visibility: Filipina/o Labour, Culture, and Youth in Canada. In Filipinos in Canada(pp. 5-45). University of Toronto Press.

Meloni, F., Rousseau, C., Montgomery, C., \& Measham, T. (2014). Children of exception: redefining categories of illegality and citizenship in Canada. Children \& Society, 28(4), 305-315.

Migrantealberta. (n.d.). Who are we. https://www.migrantealberta.ca. Accessed May 16, 2020

Migrant Rights Network. (2020). Press Conference: Essential Undocumented \& Migrant Workers Call for Emergency Income Supports During COVID-19., from https://migrantrights.ca/pressconference-essential-undocumented-migrant-workers-call-foremergency-income-supports-during-covid-19/. Accessed May 16,2020

Miklavcic, A. (2011). Canada's non-status immigrants: negotiating access to health care and citizenship. Medical Anthropology, 30(5), 496-517.
Nyers, P. (2010). No one is illegal between city and nation. Studies in Social Justice, 4(2), 127-143.

Plummer, K. (1995). Telling sexual stories: power, change and social worlds. Routledge.

Pinoy Edmonton News. (2017). Migrante AB launhes McKenna Rose Campaign https://pinoyedmontonnews.com/tag/mckennaroselaw/. Accessed August 1, 2020.

Portes, A., \& Böröcz, J. (1989). Contemporary immigration: theoretical perspectives on its determinants and modes of incorporation. The International Migration Review, 23(3), 606-630.

Rivera, P. (2020). Pandemic's impact 'worse' for caregivers, OFWS. https://usa.inquirer.net/58233/pandemics-impact-worse-forcaregivers-ofws. Accessed September 8, 2020.

Rodriguez, R. M. (2010). Migrants for export how the Philippine state brokers labor to the world. University of Minnesota Press.

Sharma, N. R. (2006). Home economics nationalism and the making of "migrant workers" in Canada (C. E. L. (Firm), ed.). Toronto, Ont.: Toronto, Ont. : University of Toronto Press.

Thobani, S. (2007). Exalted subjects : studies in the making of race and nation in Canada. University of Toronto Press.

Statista. (2020). Top 10 Origin Countries of TFWP Permit Holders Canada 2019.". https://www.statista.com/statistics/555058/top10-origin-countries-of-tfwp-permit-holders-canada/. Accessed October 1, 2020.

Tungohan, E. (2020). Settlement, separation and forming new families: a multi-scalar intersectional analysis of Filipino family immigration in Saskatchewan, Canada. Women's Studies International Forum, 83, 102403.

Tungohan, E. (2018). Temporary foreign workers in Canada: reconstructing 'belonging' and remaking 'citizenship.' Social \& Legal Studies, 27(2), 236-252.

Tungohan, E. (2017). From encountering confederate flags to finding refuge in spaces of solidarity: Filipino temporary foreign workers' experiences of the public in Alberta. Space and Polity, 21(1), 11-26. https://doi.org/10.1080/13562576.2017.1270637

UNESCO. (2017). Migrant/migration. International Migration. International Migration Convention. Retrieved from http://www.unesco. org/new/en/social-and-human-sciences/themes/internationalmigration/glossary/migrant/

Villegas, F. J. (2017). 'Access without fear!': reconceptualizing 'access' to schooling for undocumented students in Toronto. Critical Sociology, 43(7-8), 1179-1195.

Villegas, P. E. (2014). "I can't even buy a bed because I don't know if I'll have to leave tomorrow": temporal orientations among Mexican precarious status migrants in Toronto. Citizenship Studies, 18(34), 277-291. Retrieved from https://doi.org/10.1080/13621025. 2014.905269

Yin, R. (2011). Case study research: design and methods. Modern Language Journal, 95, 474.

Yin, R. K. (1994). Case study research: Design and methods. Beverly Hills, CA: Sage. 